\title{
Czy dwujęzyczność sprzyja kreatywności? Doniesienie z badań
}

\section{Does bilingualism contribute to creativity? A research report}

\author{
Justyna Heryng, Monika Obrębska \\ INSTYTUT PSYCHOLOGII, UNIWERSYTET IM. ADAMA MICKIEWICZA \\ UL. AUGUSTYNA SZAMARZEWSKIEGO 89AB, 60-568POZNAŃ \\ heryng.justyna@gmail.com, monika.obrebska@amu.edu.pl
}

\begin{abstract}
The paper discusses links between bilingualism and creativity. It begins with a theoretical introduction and then presents research results based on the Creative Behaviour Questionnaire KANH-I (Popek 2000) in a group of 107 high school students. The obtained data was used to test group differences between attendees of classes learning German bilingually and their peers following standard curriculum, which yielded no significant results. The correlation analysis between bilingualism and the dimensions of creative behaviour according to KANH-I yielded no significant results as well. Finally, possible explanations of the results are discussed, along with the limitations of the present study.
\end{abstract}

\section{Wprowadzenie}

Współczesne wartości i proces globalizacji sprzyjają dwujęzyczności, która staje się zjawiskiem coraz powszechniejszym. Coraz więcej osób podróżuje, emigruje, zmienia miejsca zamieszkania, a wysoki poziom nauki języków obcych jest sztandarowym hasłem każdej szanującej się szkoły. Najpopularniejszym drugim językiem, najczęściej używanym w oficjalnych negocjacjach ekonomiczno-politycznych, w pracach naukowych i w turystyce, jest oczywiście język angielski. Przewiduje się, że do 2050 roku połowa populacji świata będzie w mniejszym lub większym stopniu posługiwała się tym językiem. Sceptycy nazywają to zjawisko "lingwistycznym imperializmem”, odnosząc się przy tym do dominującej roli kultury amerykańskiej, tym niemniej dwu-, a nawet wielojęzyczność współczesnego świata staje się faktem (Wosińska 2010). 
Pomimo powszechności zjawiska problematyka dwujęzyczności wzbudza wśród badaczy wciąż liczne spory i kontrowersje. Zdecydowanie nie jest ona zmienną kategorialną i żaden opis nie jest $\mathrm{w}$ stanie odzwierciedlić złożoności jej fenomenu. Szczególnie narażone na krytykę są koncepcje najbardziej rygorystyczne i najbardziej liberalne. John V. Edwards (2004) rozpoczyna swoją pracę od śmiałego stwierdzenia: każdy jest dwujęzyczny. Następnie deklaruje, że nie ma na świecie osoby (a przynajmniej osoby dorosłej), która nie znałaby choć kilku słów w jakimś innym języku niż ojczysty, nawet jeśli miałyby to być utarte wyrażenia takie jak: c'est la vie, Ordnungmusssein czy hasta la vista; ich zrozumienie świadczy już o minimalnym poziomie władania drugim językiem. Przeciwne stanowisko zajmował Leonard Bloomfield (1933), który za osobę dwujęzyczną uznawał kogoś, kto w każdym z opanowanych języków potrafi wyrazić dowolną treść oraz płynnie i bez wysiłku przechodzić z jednego na drugi. Obecnie obydwa stanowiska spotykają się z krytyką, a badacze usiłują znaleźć kompromisowe rozwiązanie. Najczęściej mianem dwu- i wielojęzyczności określa się sprawność w posługiwaniu się więcej niż jednym językiem, ponieważ ścisłe kryterium pełnej biegłości spełnia niewiele osób na co dzień funkcjonujących w wielojęzycznym środowisku (Grosjean 1997; Snow 2005; Kurcz 2005, 2007). Rodzimi użytkownicy języka również popełniają błędy językowe i gramatyczne, przypadkowe lub regularnie powtarzające się (Wodniecka-Chlipalska 2011), w związku z czym ostrzejsze rozróżnienia nawet im odmówiłyby pełnej biegłości. Aby rozstrzygnąć spory EllenBialystok (2001) proponuje, by dwujęzyczność na podobieństwo innych cech ujmować jako kontinuum, którego skraje wyznaczają osoby nie znające L2 w ogóle oraz takie, które posługują się nim biegle. Takie rozumienie rozwiązuje część powyższych problemów, jednak rodzi inne pytanie: o sposób ustalania poziomu opanowania drugiego języka.

Ponieważ nie istnieje definicja, która zadowoliłaby potrzeby wszystkich badaczy, zjawisko dwujęzyczności klasyfikuje się najczęściej ze względu na kryteria kontekstowe. Jednym z nich jest podział odnoszący się do momentu nabywania drugiego języka. Dwujęzyczność równoczesna występuje u dzieci z małżeństw mieszanych, wczesna - u dzieci imigrantów, zaś późna - u dorosłych zmieniających kraj zamieszkania (Wodniecka-Chlipalska 2011). Catherine E. Snow (2005) wprowadza także dodatkowe określenie dla przyswajania dwóch języków jednocześnie od urodzenia - „dwujęzyczność rodzima”. Inna klasyfikacja wyróżnia dwujęzyczność zrównoważoną i niezrównoważoną, przy czym kryterium jest zbliżony poziom kompetencji językowej i komunikacyjnej w obu językach (Wodniecka-Chlipalska 2011). To rozróżnienie jest bliskie podziałowi Uriela Weinreicha (1953), który wspomina o dwujęzyczności współrzędnej, kiedy L1 i L2 mają odrębne systemy znaczeń, nabywane w różnych kontekstach oraz złożonej, kiedy w obu językach kształtuje się jeden wspólny system znaczeń. Ida Kurcz (2007) uzupełnia te propozycje o dwujęzyczność pełną, kiedy kompetencja językowa i komunikacyjna są rozwinięte w obu językach zarówno w mowie, jak i w piśmie. 


\section{Justyna Heryng, Monika Obrębska: Czy dwujęzyczność sprzyja twórczości? Doniesienie z badań}

Innym obszarem kontrowersji są cały czas konsekwencje poznawcze dwujęzyczności. W pracach opublikowanych przed rokiem 1960 (za: Katchan 2007) wyrażano dość pesymistyczny pogląd, według którego dwujęzyczność jest ułomnością, gdyż prowadzi do chaosu w umyśle i nadmiernego przeciążenia psychicznego. Otto Jesperson w 1922 roku twierdził, że człowiek dysponuje ograniczoną pulą zdolności intelektualnych - osoba dwujęzyczna musi tę pulę podzielić między dwa języki i jest uboższa w każdym z nich w porównaniu z osobą jednojęzyczną. Pogląd ten zakwestionowały dopiero badania Elizabeth Peal i Wallace'a Lamberta $z$ 1962 roku. Zwrócili oni uwage na fakt, że ich poprzednicy nie potrafili oddzielić czynników środowiskowych (takich jak np. status społecznoekonomiczny rodziny) od czynników dotyczących samej dwujęzyczności. Może mieć ona pozytywne skutki pod warunkiem, że porównuje się dzieci w tym samym wieku, o tym samym pochodzeniu społecznym i wykazujące się identyczną płynnością językową. W badaniu przeprowadzonym na dzieciach kanadyjskich z uwzględnieniem zmiennych demograficznych okazało się, że dzieci dwujęzyczne osiągnęły znacząco lepsze wyniki od dzieci jednojęzycznych $\mathrm{w}$ testach inteligencji, zarówno werbalnej jak i niewerbalnej. Peal i Lambert uznali, iż jest to skutkiem tego, że osoby dwujęzyczne sprawniej tworzą pojęcia, czyli umysłowe obrazy przedmiotów i zjawisk, a także łatwiej przychodzi im oderwanie się od myślowych schematów i zaproponowanie niestandardowych rozwiązań problemów dzięki rozwijanej poprzez posługiwanie się dwoma językami giętkości umysłowej.

Współcześnie rośnie liczba prac, w których wykazuje się, że dzieci osiągające dwujęzyczność wykazują w wielu obszarach przewagę poznawczą nad dziećmi z porównywalnych jednojęzycznych grup kontrolnych. Podkreśla się, że wzajemna interferencja między językami zmusza osoby dwujęzyczne do stosowania strategii przyspieszających rozwój poznawczy. Przewaga dzieci dwujęzycznych polega przede wszystkim na bardziej rozwiniętym u nich mechanizmie kontroli uwagi w procesach przetwarzania informacji niepewnych, mylących. EllenBialystok (2007) podaje, że osoby o porównywalnej znajomości obu języków (dwujęzyczność zrównoważona) lepiej wykonywały zadania dotyczące tworzenia pojęć, lepiej wypadały w testach niezależności od pola i w piagetowskich zadaniach dotyczacych stałości przedmiotów, konsekwentnie osiągały również lepsze wyniki w zakresie giętkości myślenia i oryginalności rozwiązań sytuacji problemowych, składających się na decydujące o twórczości myślenie dywergencyjne. Nie stwierdzono natomiast przewagi osób dwujęzycznych nad jednojęzycznymi przy wykonywaniu zadań odnoszących się do wiedzy deklaratywnej i do procesów logicznego myślenia.

\section{Dwujęzyczność a myślenie twórcze}

Twórczość jest pojęciem wieloznacznym, dlatego niezbyt dobrze funkcjonuje jako termin naukowy, chociaż samo zjawisko stanowi ważny i ciekawy przedmiot badań. Najczęściej definiuje się ją jako proces psychiczny prowadzący do wytworzenia nowej i wartościowej idei (Nęcka 
2012). Jako jej składniki wymienia się procesy poznawcze (uwaga, percepcja, wyobraźnia, pamięć i myślenie), a także stany emocjonalne i cechy osobowości. Za szczególnie istotną dla procesu twórczego uznaje się umiejętność myślenia dywergencyjnego, zwanego również często myśleniem twórczym. W przeciwieństwie do myślenia konwergencyjnego, polegającego na poszukiwaniu jednego poprawnego rozwiązania, myślenie dywergencyjne sprowadza się do wytwarzania licznych pomysłów w odpowiedzi na problem natury otwartej. Joy P. Guilford (1978), który jest autorem tego podziału, wymienia trzy kryteria oceny myślenia dywergencyjnego: płynność, giętkość i oryginalność. Płynność definiuje się jako łatwość wytwarzania pomysłów, a operacjonalizuje poprzez ich liczbę, giętkość jest gotowością do zmiany kierunku myślenia; operacyjnym wskaźnikiem tej zdolności może być różnorodność pomysłów, czyli liczba kategorii, do jakich można je zaliczyć. Z kolei oryginalność to zdolność do wytwarzania reakcji nietypowych, niezwykłych, niepowtarzalnych.

Myślenie dywergencyjne badane było często w kontekście dwujęzyczności. Richard G. Landry (1974) dowiódł, że wpływ dwujęzyczności na ten typ myślenia rośnie wraz $\mathrm{z}$ wiekiem badanych. Poprzez proces przezwyciężania negatywnego transferu pomiędzy dwoma systemami językowymi rozwijana jest giętkość poznawcza, korzystna dla późniejszego myślenia dywergencyjnego. Przebadane przez niego dzieci dwujęzyczne uzyskały znacząco wyższe wyniki nie tylko w zakresie giętkości, ale również w zakresie płynności i oryginalności skojarzeń. Podobne wyniki uzyskała Lina A. Ricciardelli (1992) wskazując na przewagę osób dwujęzycznych w zakresie twórczości i giętkości myślenia oraz AnatoliyKharkhurin (2008) badając poziom kreatywności dwujęzycznych osób dorosłych.

Zdaniem Bialystok (2007) przekonanie, że dwujęzyczność może mieć wpływ na niewerbalny rozwój poznawczy, w tym na myślenie twórcze, opiera się na założeniu, że wiedza językowa i niejęzykowa bazują na wspólnych niespecyficznych zasobach systemu reprezentacji i w związku z tym mogą na siebie wzajemnie oddziaływać. Wymaga to przyjęcia założenia o istnieniu nadrzędnego mechanizmu wspólnego procesom językowym i niejęzykowym. Modele, które przewidują istnienie takiego wspólnego mechanizmu, odwołują się zazwyczaj do tak zwanych funkcji wykonawczych, które podlegają ograniczeniom procesów reprezentacji i pamięci roboczej, a ich działanie limitowane jest przez ogólne zasoby odpowiedzialne za uwagę wybiórczą, procesy hamowania i planowania. Jeżeli dwujęzyczność, jak podkreśla Bialystok, wywiera rzeczywiście fundamentalny wpływ na niewerbalny rozwój poznawczy, to niewykluczone, że dokonuje się on poprzez oddziaływanie dwujęzyczności na ogólną funkcję wykonawczą systemu poznawczego.

W celu wyjaśnienia tego problemu David Green (1998) zaproponował tak zwany model kontroli hamującej, w którym akcentuje się rolę systemu kontrolnego uwagi wybiórczej (supervisoryattentional system - SAS), nadzorującego przełączanie kodu i zamykanie lub otwieranie dostępu do poszczególnych języków. Jest on z natury rzeczy lepiej rozwinięty u osób 


\section{Justyna Heryng, Monika Obrębska: Czy dwujęzyczność sprzyja twórczości? Doniesienie z badań}

dwujęzycznych, ponieważ procesy hamowania są aktywowane za każdym razem, gdy używany jest jeden lub drugi język. W związku z tym u dzieci dwujęzycznych w pierwszych latach życia funkcje wykonawcze są intensywnie ćwiczone. Trening ten przenosi się przy okazji także na inne procesy hamowania, niezwiązane $\mathrm{z}$ językiem, i w konsekwencji osoby dwujęzyczne cechuje wyższa sprawność we wszelkich zadaniach wymagających hamowania mylących informacji, otwartości problemowej i tolerancji niezgodności. Za przykład posłużyć tu mogą zadania badające poziom twórczości, w których badani wymyślają niecodzienne zastosowania zwyczajnych przedmiotów. Jak zauważa Bialystok (2007), zadania te wymagają stłumienia chęci konwencjonalnego wykorzystania przedmiotu i rozważenia innych możliwości. Trzeba umieć zignorować informację związaną z podstawowym wykorzystaniem przedmiotu i „wyhamować” jego konwencjonalne zastosowanie.

Postulat Peal i Lamberta, że dwujęzyczność rozwija giętkość umysłową i myślenie twórcze pozostaje więc nadal aktualny, a ponadto zyskuje wsparcie w postaci nowych danych empirycznych i modeli teoretycznych. Zdaniem wielu badaczy umiejętność opisania świata na dwa sposoby pozwala osobom dwujęzycznym zrozumieć, iż wiele rzeczy może być inaczej spostrzeganych i interpretowanych z wykorzystaniem wielu perspektyw. A to $\mathrm{w}$ konsekwencji prowadzi do większej giętkości w procesach percepcji i interpretacji oraz do większej otwartości na nowe lub złożone doświadczenia. I w tym kontekście twórczość może być rzeczywiście - jak pisze Bialystok (2007: 290) - „beneficjentem dwujęzyczności”, przynajmniej w takim zakresie, w jakim jest ona badana za pomocą testów psychologicznych.

\section{Problem i metoda badań własnych}

W badaniu własnym postanowiono sprawdzić, czy rzeczywiście dwujęzyczność sprzyja myśleniu twórczemu. Sposób rozumienia twórczości w tej pracy wyznacza koncepcja Stanisława Popka (2000), podkreślająca wpływ sfer poznawczej i osobowościowej na zachowania twórcze. Obie sfery są ciągłe i wyznaczone przez cechy mieszczące się na ich przeciwnych biegunach, są to odpowiednio: zachowanie algorytmiczne (A) i zachowanie heurystyczne $(\mathrm{H})$ oraz konformizm $(\mathrm{K})$ i nonkonformizm $(\mathrm{N})$. Zachowanie algorytmiczne oznacza sztywność myślenia i bazowanie na schematach, a zachowanie heurystyczne opieranie się na wyobraźni i intuicji. Konformizm przejawia się poprzez podporządkowanie autorytetom i brak inicjatywy, zaś nonkonformizm to umiejętność podkreślania własnej indywidualności mimo presji społecznej. Te czynniki są następnie grupowane parami w dwie postawy: odtwórczą $(\mathrm{K}+\mathrm{A})$ i twórczą $(\mathrm{N}+\mathrm{H})$.

Ramy dwujęzyczności na potrzeby badania wyznaczyła klasyfikacja Europejskiego Systemu Opisu Kształcenia Językowego (CommonEuropean Framework of Reference for Languages, CEFR). Obejmuje ona sześć poziomów - A1, A2, B1, B2, C1, C2 - których osiągnięcie zależy od wykazania określonych kompetencji w czterech obszarach: czytaniu, słuchaniu, mówieniu i pisaniu. Szczegółowe informacje są dostępne w publikacji Rady 
Europy (Council of Europe 2001) oraz jej polskim tłumaczeniu (Rada Europy 2003).

Grupę badaną stanowili uczniowie drugich i trzecich klas VII Liceum Ogólnokształcącego im. Dąbrówki w Poznaniu. Dwujęzyczność oceniono na podstawie autoewaluacji biegłości językowej badanych $\mathrm{w}$ oparciu o Europejski System Opisu Kształcenia Językowego, poziom twórczości zbadano natomiast Kwestionariuszem Twórczego Zachowania KANH-I Stanisława Popka.

Pierwotnie badanie miało mieć charakter wyłącznie porównawczy. Założono, że uczniowie klas dwujęzycznych, realizujących język niemiecki w trybie rozszerzonym oraz część treści pozostałych przedmiotów w tym języku już od poziomu gimnazjum, cechować się będą, zgodnie z opisanymi wcześniej założeniami teoretycznymi, wyższym poziomem twórczości niż uczniowie $\mathrm{z}$ klas o normalnym (jednojęzycznym) trybie nauczania. Utrudniła to nieprzewidziana zmiana $\mathrm{w}$ systemie kształcenia języków obcych w VII LO, polegająca na tworzeniu grup międzyoddziałowych. Z przyczyn organizacyjnych i czasowych nie podjęto próby przeprowadzenia badań w niedwujęzycznych grupach językowych zamiast w klasach, co prawdopodobnie przyniosłoby inne rezultaty. Przewidując, że może to wpłynąć na zróżnicowanie poziomu dwujęzyczności w obu grupach obok hipotez różnicowych sformułowano także korelacyjne oraz uzupełniono część demograficzną kwestionariusza o pytanie dotyczące samooceny znajomości języków obcych przez badanych, ponieważ zignorowanie wpływu języków innych niż niemiecki na dwujęzyczność byłoby nieuprawnione. Przełożyło się to na następujące hipotezy badawcze:

$>\mathrm{H}_{1}$ : Uczniowieklasdwujęzycznychcechująsięwyższympoziomemzachowa ńtwórczychniżuczniowieklasniedwujęzycznych

$>\mathrm{H}_{2}$ : Dwujęzycznośćkorelujedodatnio z zachowaniamitwórczymi

W celu weryfikacji powyższych hipotez przeprowadzono badanie na grupie 52 uczniów klas dwujęzycznych i 55 uczniów klas niedwujęzycznych VII Liceum Ogólnokształcącego im. Dąbrówki w Poznaniu. Badani wypełniali kwestionariusze grupowo, w trakcie zajęć, metodą papierołówek. Wszyscy uczniowie wyrazili pisemną zgodę na udział w badaniu, w przypadku uczniów niepełnoletnich zgodę wyrazili również ich rodzice.

Sposób doboru grupy wpłynął na strukturę jej wieku. Wartość minimalna wyniosła 16 , a maksymalna 19 lat, jednak 93,4\% badanych miało 17 i 18 lat (po 46,7\% i 50 osób), co zaowocowało średnią rzędu 17,43. Ze względu na zastosowanie doboru celowego wiek badanych ma jednak znaczenie drugorzędne. Jeżeli chodzi o liczebność płci, 59,8\% stanowiły kobiety (64 osoby), 39,3\% mężczyźni (42 osoby), a jedna osoba nie udzieliła odpowiedzi.

\section{Analiza wyników badań własnych}




\section{Justyna Heryng, Monika Obrębska: Czy dwujęzyczność sprzyja twórczości? Doniesienie z badań}

W celu testowania różnic międzygrupowych dwujęzyczność oceniono przez pryzmat przynależności do klasy, w związku z czym podzielono badanych na dwie podgrupy - dwujęzycznych (2E i 3E, łącznie 52 osoby, 48,6\%) i niedwujęzycznych (2B i 3C, 55 osób, 51,4\%). Wynik testu KołmogorowaSmirnowa dla jednej próby pozwolił na stwierdzenie braku normalności rozkładu zmiennej „dwujęzyczność” (przy $p \leq 0,01$ ).

W związku z tym istotnie wyższe natężenie dwujęzyczności u uczniów klas $\mathrm{z}$ bilingwalnym programem kształcenia językowego wykazano z użyciem testu $U$ Manna-Whitneya dla grup niezależnych ( $p \leq 0,01$, $U=542,000$, średnia ranga dla grupy dwujęzycznej 71,08, a dla niedwujęzycznej 37,85). Stanowi to argument potwierdzający założenie, że przynależność do klasy można zastosować jako zmienną różnicującą poziom zmiennych zależnych.

Wskaźnikiem korelacji stała się natomiast najwyższa wartość spośród języków zadeklarowanych jako znane. Liczbowo mógł on wynieść od o do 6. Dla przejrzystości pozostano przy kodach poziomów Europejskiego Systemu Oceny Kształcenia Językowego. W badaniu wartość minimalna wyniosła 2 (poziom A2), a maksymalna najwyższy możliwy, czyli 6 (poziom C2). Średni wskaźnik wyniósł 4,22, czyli wartość przewyższającą poziom 4 (B2), na którym uplasowało się aż 48,6\% badanych (52 osoby). Kolejne $28 \%$ (30 osób) osiągnęło poziom $5(\mathrm{C} 1)$. Tabela 1 przedstawia zbiorczo wskaźniki statystyczne dla wszystkich testowanych hipotez.

Tabela 1. Wyniki weryfikacji hipotez dotyczących relacji dwujęzyczności z wymiarami twórczości

\begin{tabular}{|c|c|c|c|c|c|}
\hline & \multicolumn{3}{|c|}{$\mathrm{H}_{1}$ : Testy różnic międzygrupowych } & \multicolumn{2}{|c|}{$\mathrm{H}_{2}$ : Korelacje } \\
\hline & $p$ & $U$ & $M R$ & $p$ & $r$ \\
\hline Konformizm & 0,35 & 1256,50 & $\begin{array}{l}\text { D: } 56,36 \\
\text { N: } 50,85\end{array}$ & 0,49 & $-0,01$ \\
\hline $\begin{array}{l}\text { Zachowanie } \\
\text { algorytmiczne }\end{array}$ & 0,09 & 1117,00 & $\begin{array}{l}\text { D: } 47,98 \\
\text { N: } 57,92\end{array}$ & 0,19 & $-0,09$ \\
\hline Nonkonformizm & 0,13 & 1146,50 & $\begin{array}{l}\text { D: } 57,45 \\
\mathrm{~N}: 48,63\end{array}$ & 0,09 & 0,14 \\
\hline $\begin{array}{l}\text { Zachowanie } \\
\text { heurystyczne }\end{array}$ & 0,30 & 1190,00 & $\begin{array}{l}\text { D: } 55,71 \\
\text { N: } 49,64\end{array}$ & 0,12 & 0,12 \\
\hline $\begin{array}{l}\text { Postawa } \\
\text { odtwórcza }\end{array}$ & 0,88 & 1329,00 & $\begin{array}{l}\mathrm{D}: 52,06 \\
\mathrm{~N}: 52,92\end{array}$ & 0,40 & $-0,02$ \\
\hline Postawa twórcza & 0,24 & 1121,50 & $\begin{array}{l}\text { D: } 55,11 \\
N: 48,16\end{array}$ & 0,12 & 0,12 \\
\hline
\end{tabular}

Adnotacja: $r$ - współczynnik korelacji, $p$ - istotność jednostronna, $M R$ - średnie rangi dla grup, D grupa dwujęzyczna, $\mathrm{N}$ - grupa niedwujęzyczna. 
Średni wynik postawy twórczej okazał się wyższy w grupie uczniów dwujęzycznych $(M=55,11)$ w porównaniu z grupą uczniów o normalnym trybie nauczania $(M=48,16)$, co jest zgodne z kierunkiem zakładanej hipotezy badawczej. Uczniów dwujęzycznych cechuje również wyższy poziom nonkonformizmu i myślenia heurystycznego niż uczniów jednojęzycznych. Różnice te okazały się jednak zbyt małe, by uzyskać istotność na poziomie statystycznym. Najbliższe przyjętemu poziomowi $\alpha=$ 0,05 były wyniki skal Zachowanie algorytmiczne $(p=0,09)$, przy czym wyższą średnią rangę uzyskali uczniowie klas niedwujęzycznych oraz Nonkonformizm ( $p=0,13)$, w której wyższą średnią rangę uzyskali uczniowie klas dwujęzycznych.

Odrzucona została również hipoteza korelacyjna. Nie stwierdzono istotnego związku między poziomem dwujęzyczności a żadnym z wymiarów twórczości. Najbliższy przyjętemu poziomowi $\alpha=0,05$ jest wynik skali Nonkonformizm $(p=0,09)$.

\section{Dyskusja}

Wyniki uzyskane $\mathrm{w}$ przedstawionym badaniu wykazują, że między licealistami uczącymi się niemieckiego dwujęzycznie i ich rówieśnikami z klas realizujących standardowy program nauczania nie ma istotnych statystycznie różnic wpoziomie zachowań twórczych, mimo stwierdzenia istotnej różnicy w natężeniu dwujęzyczności między grupami. Może to oznaczać, że w kontekście tych cech, przynajmniej w zbadanej grupie, większe znaczenie niż tryb i intensywność uczenia się języka obcego mają inne czynniki.

Ograniczeniem badania własnego było $\mathrm{z}$ pewnością zastosowanie doboru celowego, gdyż przebadana grupa nie jest reprezentatywna dla populacji. Jednym z powodów zbliżonego poziomu cech może być ogólny poziom kształcenia i szans edukacyjnych, ponieważ wszyscy badani uczą się w liceum mieszczącym się w dużym mieście i osiągającym dobre wyniki (według rankingu „Perspektyw” dla Wielkopolski 13 miejsce w roku 2016

i 11 miejsce w roku 2017²). Ponadto analiza danych wykazała, że założenie o wyższym poziomie dwujęzyczności uczniów klas „E” nie było w pełni trafne - uzyskali oni co prawda istotnie wyższy wynik oraz wyższą średnią grupową w zakresie biegłości językowej, jednak wśród osób z pozostałych klas także znalazły się osoby o wysokim poziomie znajomości języków obcych, głównie angielskiego. Wobec tego warto byłoby przy innej okazji porównać osoby kształcone dwujęzycznie z grupą młodzieży jednojęzycznej nie znającej żadnego innego języka, jednak współcześnie nauczanie języków obcych zajmuje istotne miejsce $\mathrm{w}$ polskim systemie oświatowym oraz jest ważne $\mathrm{z}$ perspektywy samych uczniów, między innymi wkontekście zwiększania możliwości edukacyjnych, a następnie szans na rynku pracy.

1http://www.perspektywy.pl/portal/index.php?option=com_content\&view=article\&id=2517:ranking-liceow-2016-wojwielkopolskie\&Itemid=351\&strona=1 [data dostępu: 27 września 2017]

2http://www.perspektywy.pl/portal/index.php?option=com_content\&view=article\&id=3236:ranking-liceow-2017-wojwielkopolskie\&catid=221\&Itemid=424\&strona=1 [data dostępu: 27 września 2017] 


\section{Justyna Heryng, Monika Obrębska: Czy dwujęzyczność sprzyja twórczości? Doniesienie z badań}

Znalezienie odpowiednio dużej liczby takich osób mogłoby się zatem okazać trudne, a gdyby się powiodło, źródłem zróżnicowania mógłby być niski ogólny poziom kształcenia lub czynniki socjoekonomiczne, nie zaś poziom znajomości języka obcego.

Przyczyną braku istotnych różnic międzygrupowych może być również fakt, że większość badanych uzyskała wysoki współczynnik dwujęzyczności $(M=4,22)$. Zgodnie $\mathrm{z}$ przyjętym sposobem ustalania poziomu dwujęzyczności wszyscy badani mieścili się na skali pięciostopniowej pomiędzy drugim a szóstym poziomem, zaś 52 spośród wszystkich 107 osób, czyli 48,6\% całej grupy, znajdowało się w połowie skali, na poziomie odpowiadającym wyższemu średniozaawansowanemu. W związku z tym stosowany często w testach różnic podział grupy badanej według mediany zmiennej grupującej, służący uzyskaniu bardziej homogenicznych podgrup, nie rozwiązałby tego problemu w całości, ponieważ osoby z tego poziomu znalazłyby się w obu w porównywalnej liczbie. Z kolei ograniczenie się do porównania grup o niskim i wysokim poziomie dwujęzyczności, złożonych odpowiednio z osób początkujących i średniozaawansowanych (18 osób) oraz zaawansowanych i biegłych (37 osób) było niemożliwe ze względu na ich nierównoliczność, a ogólnie mniejsza liczebność grup wpłynęłaby także na rzetelność wyników. Byłoby to jednak prawdopodobnie najwłaściwsze rozwiązanie w przypadku przebadania większej grupy.

W odróżnieniu od testów różnic międzygrupowych, które w zasadzie zbadały różnicującą wartość programu kształcenia (a nie dwujęzyczności jako takiej) dla zmiennych zależnych, celem analiz korelacji było przetestowanie związków zachowań twórczych ze stopniem biegłości językowej w całej grupie. W przypadku żadnego z wymiarów twórczości korelacje nie były istotne, co świadczy o braku związków między nimi a poziomem znajomości języków obcych. Nie potwierdziło się zatem oczekiwanie wywiedzione na podstawie wyników badań wykazujących różnice między osobami zaklasyfikowanymi jako jedno- i dwujęzyczne, że natężenie dwujęzyczności będzie istotnie związane $\mathrm{z}$ zachowaniami twórczymi.

Na koniec warto również zauważyć, że większość cytowanych badań nad związkiem dwujęzyczności $\mathrm{z}$ myśleniem twórczym dotyczyła jednak myślenia dywergencyjnego, nie zaś heurystycznego i nonkonformizmu, które zdaniem Popka składają się na postawę twórczą. Być może nieco inna operacjonalizacja zmiennej „twórczość” wpłynęła również na niespójność uzyskanych rezultatów z klasycznymi badaniami. Tym bardziej zachęca to jednak do dalszych badań nad dwujęzycznością i poszukiwania innych, istotnych jej „beneficjentów”. 


\section{InvestigationesLinguisticae, vol. XLII}

\section{Bibliografia}

Bialystok, E. 2001. Bilingualism in development: language, literacy and cognition. New York: Cambridge University Press.

Bialystok, E. 2007. Wpływ dwujęzyczności na rozwój poznawczy. w: I. Kurcz (Ed.) Psychologiczne aspekty dwujęzyczności. Gdańsk: Gdańskie Wydawnictwo Psychologiczne. pp. 269-295.

Bloomfield, L. 1933. Language. Oxford: Holt.

Council of Europe. 2001. CommonEuropean Framework of Reference for Languages: Learning, teaching, assessment. Cambridge: Cambridge University Press.

Edwards, J. V. 2004. Foundations of bilingualism. w: T. K. Bhatia, W. C. Ritchie (Eds.) Handbook of bilingualism. Oxford: Blackwell. pp. 7-31.

Green, D. W. 1998. Mental control of the bilingual lexico-semantic system. Bilingualism: Language and Cognition, vol. 1, pp. 67-81.

Grosjean, F. 1997. Processing mixed languages: issues, findings and models. w: A. M. B. de Groot, J. F. Kroll (Eds.) Tutorials in bilingualism: psycholinguistic perspectives. Mahwah, NJ: Erlbaum. pp. 225-253.

Guilford, J. P. 1978. Natura inteligencji czlowieka. Warszawa: Wydawnictwo PWN.

Jesperson, O. 1922. Language. New York: Holt.

Katchan, O. 2007. Wczesna dwujęzyczność - sprzymierzeniec czy nieprzyjaciel? w: I. Kurcz (Ed.) Psychologiczne aspekty dwujęzyczności. Gdańsk: Gdańskie Wydawnictwo Psychologiczne. pp. 155-172.

Kurcz, I. 2005. Psychologia języka i komunikacji. Warszawa: Wydawnictwo Scholar.

Kurcz, I. 2007. Jakie problemy psychologiczne może rodzić dwujęzyczność? w: I. Kurcz (Ed.) Psychologiczne aspekty dwujęzyczności. Gdańsk: Gdańskie Wydawnictwo Psychologiczne. pp. 9-39.

Kharkhurin, A. 2008. The effect of linguistic proficiency, age of second language acquisition, and length of exposure to a new cultural environment on bilinguals' divergent thinking. Bilingualism: Language and Cognition, vol. 11, pp. 225243.

Landry, R. S. 1974. A comparison of second language learners and monolinguals on divergent thinking tasks at the elementary school level. The Modern Language Journal, vol. 58, pp. 10-15.

Nęcka, E. 2012. Psychologia twórczości. Gdańsk: Gdańskie Wydawnictwo Psychologiczne.

Peal, E., Lambert, W. E. 1962. The relation of bilingualism to intelligence. Psychological Monographs, vol. 76, pp. 1-23.

Popek, S. 2000. KwestionariuszTwórczegoZachowania KANH. Lublin: Wydawnictwo UMCS.

Rada Europy. 2003. Europejski system opisuksztatceniajęzykowego: uczeniesię, nauczanie, ocenianie. Warszawa: WydawnictwaCentralnegoOśrodkaDoskonaleniaNauczycieli.

Ricciardelli, L. A. 1992. Bilingualism and cognitive development in relation to threshold theory. Journal of PsycholinguisticResearch, vol. 21, pp. 301-316.

Snow, C. E. 2005. Dwujęzyczność i przyswajanie języka drugiego. w: J. B. Gleason, N. B. Ratner (Eds.) Psycholingwistyka. Gdańsk: Gdańskie Wydawnictwo Psychologiczne. pp. 477-506.

Weinreich, U. 1953. Languages in contact. New York: Linguistic Circle of New York. 


\section{Justyna Heryng, Monika Obrębska: Czy dwujęzyczność sprzyja twórczości? Doniesienie z badań}

Wodniecka-Chlipalska, Z. 2011. Dwujęzyczność. Właściwości dwujęzycznego umysłu i specyfika badań psychologicznych nad dwujęzycznością. w: I. Kurcz, H. Okuniewska (Eds.) Język jako przedmiot badań psychologicznych. Psycholingwistyka ogólna $i$ neurolingwistyka. Warszawa: Wydawnictwo Szkoły Wyższej Psychologii Społecznej Academica. pp. 253-284.

Wosińska, W. 2010. Oblicza globalizacji. Sopot: Wydawnictwo Smak Słowa. 